\title{
Relationship of Spiritual Caring with Quality of Live for Hemodialysis Patients: A Literature Review
}

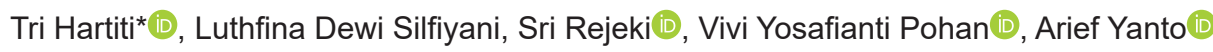 \\ Department of Nursing, Faculty of Nursing and Health Sciences, Universitas Muhammadiyah Semarang, Semarang, Indonesia
}

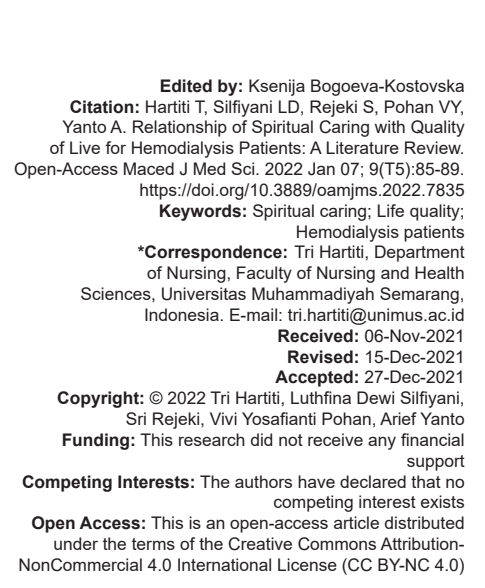

\begin{abstract}
BACKGROUND: The frequency of hemodialysis therapy routinely affected change in the functional state of the body. Support is one of the factors that can affect life quality. One of the supports can come from nurses through a spiritual caring attitude.

AIM: The purpose of this study is to determine the relationship between spiritual caring and the life quality of patients who were undergoing hemodialysis.

METHOD: A literature review was obtained from PubMed and Google Scholar databases (2015-2020) with the keywords Spiritual Care AND Life quality AND Patients with Hemodialysis.

RESULTS: Based on nine journals that have been reviewed, spiritual caring behavior that was applied in the form of intervention or spiritual therapy had been proven to have a positive impact on the life quality of patients undergoing hemodialysis. Spiritual interventions in the form of spiritual counseling, deep breathing relaxation exercises based on spiritual elements, and therapy combined with elements of prayer and dhikr were able to give the spirit of the patient in dealing with the illness. Overall, spiritual intervention affected the life quality with $p=0.000-0.032(\alpha=0.05)$, increasing the life quality in physical, psychological, and social and environmental relations.

CONCLUSION: The results show a relationship of spiritual caring with the life quality of patients undergoing hemodialysis.
\end{abstract}

\section{Introduction}

Palliative care is one approach to improve the life quality of patients and families experiencing terminal disease-related problems. One of them is in patients with chronic renal failure (CRF) [1]. The incidence rate of CRF in Indonesia based on the Basic Health Research results in 2018 increased as much as 713,783 cases from 499,800 cases in 2013. Central Java Province is one of the regions that had an incidence rate of CRF of 96,794 cases in 2018 [2].

CRF can increase the risk of morbidity and mortality and symptom burden. Global Burden of Disease study in 2015 estimated that 1.2 million deaths from cardiovascular disease are directly associated with decreased renal filtration [3]. Hemodialysis is the treatment of choice for CRF patient handling. The number of using hemodialysis therapy in Indonesia based on the results of RISKESDAS in 2018 was 2850 patients, while in Central Java Province, there were 422 patients [2]. HD action performed during $\pm 4 \mathrm{~h}$ with a frequency of visits twice a week can affect the functional state and life quality of CRF patients [4].

Research on CRF patients in the hemodialysis room at Ambarawa Regional Hospital showed that
25 respondents $(61 \%)$ had poor life quality and 16 respondents $(39 \%)$ had good life quality [5]. CRF patients will experience changes in the economy, family, freedom, work, and social life [6]. In addition, studies on CRF patients in Semarang Regional Public Hospital mostly experienced mild depression as much 41 people $(48.2 \%)$ with symptomatic signs including loss of interest and feeling of joy, reduced concentration and attention, self-esteem, and reduced self-confidence [7]. CRF will increase the emotional pressure and spiritual pressure of the patient. Therefore, the focus of service is not only on the disease but also on all aspects, both physical-psycho-social and even in the spiritual dimension [8].

Spiritual and religious dimensions are the aspects that are most chosen, felt, and needed by patients with a terminal illness [9]. Spiritual approaches can be used as a therapy to reduce depression in CKD patients [10]. The results of another study explain that spirituality strengthening training is effective in reducing the level of anxiety and depression in patients receiving hemodialysis treatment [11].

The importance of spirituality aspects for CRF patients is one way to increase meaning and life expectancy, improve life quality, increase self-confidence, and reduce patient anxiety [12]. Besides that, social support is the primary support 


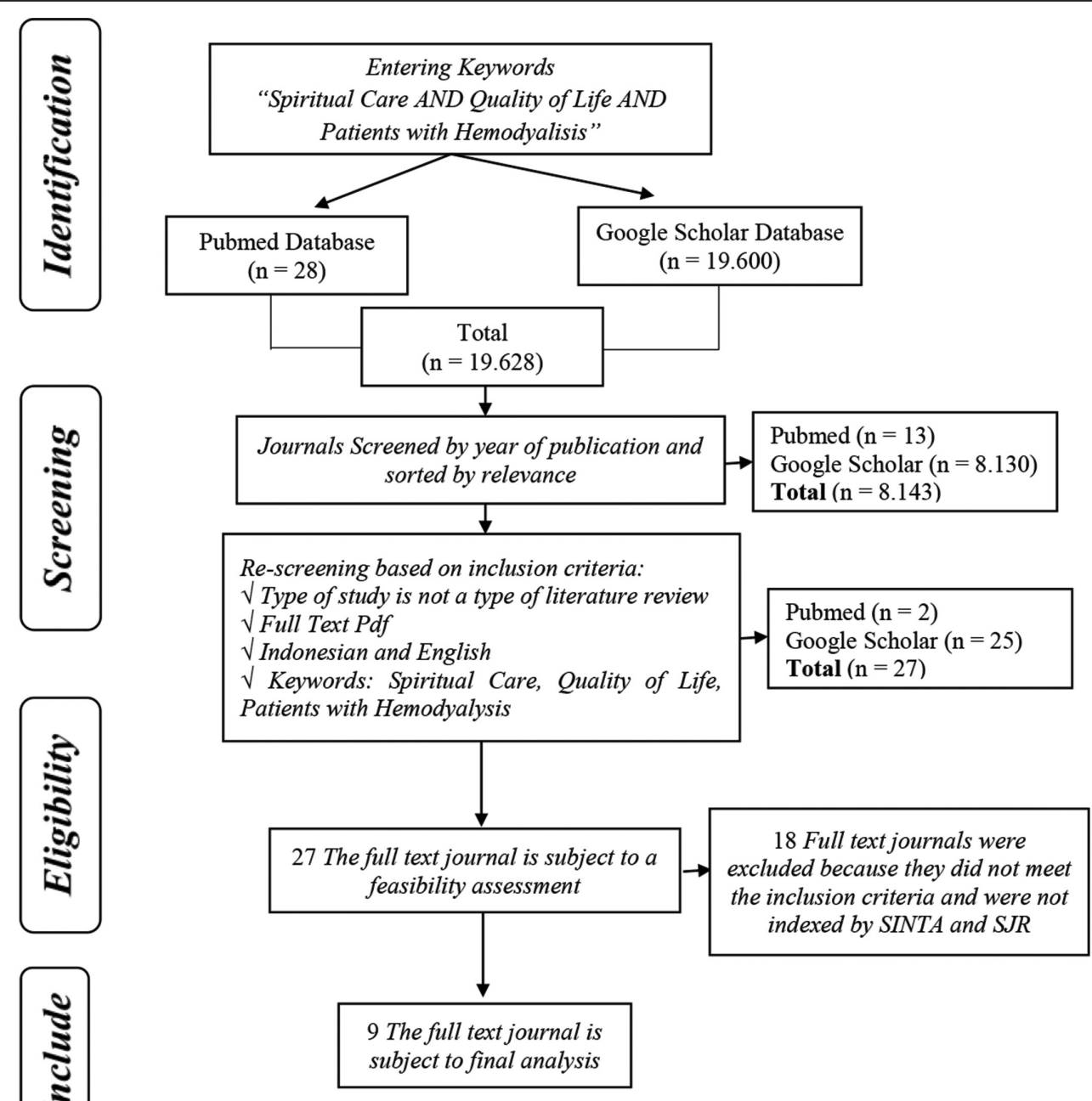

Figure 1: PRISMA flow

in managing problems faced by patients. One of the social supports comes from health workers, namely, nurses [13]. Nurses are required to provide holistic and comprehensive services, one of which includes the spiritual-religious needs of patients. The health system can include spiritual evaluation and care of hemodialysis patients [14]. The spiritual dimension is the most profound and most essential source of healing for overcoming patient problems [15].

Patients with terminal conditions such as CRF have high hopes of recovering from their illnesses. That expectation can appear as hope to God because God is the highest source of substance/strength [16]. For a Muslim, putting trust and strong belief in God is believed to be a factor that can help cure a patient's illness. Nurses also play an essential role in helping achieve patient well-being, one of which is the practice of spiritual service by providing a sense of security and a relationship of trust where nurses trust the beliefs and beliefs that patients have.

The researcher felt interested and thought about doing a journal study related to whether there was a relationship between spiritual caring and the life quality of hemodialysis patients.

\section{Methods}

The research design in this study used a literature review. This research was conducted by searching literature from the PubMed database and Google Scholar about the topic of spiritual caring with the life quality of hemodialysis patients. The article search strategy by the PICO framework uses English terms with keywords: Spiritual care AND Life quality AND Patients with Hemodialysis. Research articles compiled will be sorted according to inclusion and exclusion criteria, and then, a review or analysis will be conducted.

Searching data by entering the keywords Spiritual Care AND Life quality AND Patients with Hemodialysis obtained 19,628 research articles with details including PubMed database (28 articles) and Google Scholar database $(19,600$ articles). Then, the researchers screened through the publication year and sorted based on the relevance, obtained 8143 research articles. The remaining articles were screened again based on inclusion criteria that have been determined, leaving 27 articles, and then, a feasibility study was conducted to leave nine research articles. That article is analyzed thoroughly to 
Table 1: Differences in the research journals

\begin{tabular}{|c|c|c|c|c|c|c|}
\hline \multirow[t]{2}{*}{ No. } & \multirow[t]{2}{*}{ Article title } & \multirow[t]{2}{*}{ Researcher name, year } & \multirow[t]{2}{*}{ Journal name } & \multicolumn{3}{|c|}{ Differences in research articles/journals } \\
\hline & & & & Research design & Research place & Number of samples \\
\hline 1. & $\begin{array}{l}\text { The Effect of Spiritual Care Based on } \\
\text { Sound Heart Model on Life quality in } \\
\text { Hemodialysis Patients }\end{array}$ & Mazandarani et al. (2018) & $\begin{array}{l}\text { Journal of Psychiatry } \\
\text { and Behavioral Health } \\
\text { Forecast (Q3) }\end{array}$ & $\begin{array}{l}\text { Semi-experimental } \\
\text { study }\end{array}$ & $\begin{array}{l}\text { RS Baqiyatallah } \\
\text { Tehran, Iran }\end{array}$ & 32 patients \\
\hline 2. & $\begin{array}{l}\text { Influence of Religiosity and Spiritual } \\
\text { Coping on Health-Related Life quality } \\
\text { Saudi Hemodialysis Patients }\end{array}$ & Cruz et al. (2016) & $\begin{array}{l}\text { Hemodialysis } \\
\text { International (Q2) }\end{array}$ & Descriptive & $\begin{array}{l}\text { Tiga rumah sakit di } \\
\text { Provinsi Riyadh, Saudi } \\
\text { Arabia }\end{array}$ & 168 patients \\
\hline 3. & $\begin{array}{l}\text { Peningkatan Kualitas Hidup Patients } \\
\text { Hemodialisa Ditinjau dari Perilaku Caring } \\
\text { Perawat di RSUD dr. Soetomo Surabaya }\end{array}$ & Fadilah et al. (2016) & $\begin{array}{l}\text { Jurnal Kesehatan } \\
\text { Manarang (S3) }\end{array}$ & $\begin{array}{l}\text { Cross-sectional } \\
\text { study }\end{array}$ & $\begin{array}{l}\text { RSUD Dr. Soetomo } \\
\text { Surabaya }\end{array}$ & 70 patients \\
\hline 4. & $\begin{array}{l}\text { Hubungan Spiritualitas terhadap } \\
\text { Kualitas Hidup Patients Chronic } \\
\text { Kidney Disease (CKD) yang Menjalani } \\
\text { Hemodialisis }\end{array}$ & Yunita (2019) & $\begin{array}{l}\text { Seminar Nasional } \\
\text { Keperawatan }\end{array}$ & $\begin{array}{l}\text { Cross-sectional } \\
\text { study }\end{array}$ & $\begin{array}{l}\text { Rumah Sakit Pusri } \\
\text { Palembang }\end{array}$ & 59 patients \\
\hline 5. & $\begin{array}{l}\text { The Effects of Spiritual Care on } \\
\text { Depression and Meaning in Life in the } \\
\text { Clients with Kidney Failure Receiving } \\
\text { Hemodialysis in Rumah Sakit Islam } \\
\text { Surabaya }\end{array}$ & Wijayanti and Joni (2017) & $\begin{array}{l}\text { International Journal } \\
\text { of Science and } \\
\text { Research (IJSR) }\end{array}$ & $\begin{array}{l}\text { Quasi-experiment } \\
\text { dengan pendekatan } \\
\text { pretest-posttest } \\
\text { with control group } \\
\text { design }\end{array}$ & RS Islam Surabaya & 34 patients \\
\hline 6. & $\begin{array}{l}\text { Effect of Sleep Hygiene and Deep } \\
\text { Breathing Exercise with Spiritual Care } \\
\text { on Sleep Quality and Life quality } \\
\text { Hemodialysis Patient in Ahmad Yani } \\
\text { Islamic Hospital Surabaya }\end{array}$ & Hasina et al. (2018) & $\begin{array}{l}\text { Indonesian Journal of } \\
\text { Nursing and Midwifery (S3) }\end{array}$ & $\begin{array}{l}\text { Quasi-experiment } \\
\text { dengan pendekatan } \\
\text { pretest-posttest } \\
\text { with control group } \\
\text { design }\end{array}$ & $\begin{array}{l}\text { Rumah Sakit Islam } \\
\text { Ahmad Yani Surabaya }\end{array}$ & 38 patients \\
\hline 7. & $\begin{array}{l}\text { The Effectiveness of Spiritual Therapy } \\
\text { on Spiritual Well-Being, Self-Esteem and } \\
\text { Self-Efficacy in Patients on Hemodialysis }\end{array}$ & Darvishi et al. (2019) & $\begin{array}{l}\text { Journal of Religion and } \\
\text { Health (Q1) }\end{array}$ & $\begin{array}{l}\text { Quasi-experiment } \\
\text { dengan pendekatan } \\
\text { pretest-posttest } \\
\text { with control group } \\
\text { design }\end{array}$ & $\begin{array}{l}\text { RS Pemerintah Shahid } \\
\text { Mostafa di Ilam, Iran }\end{array}$ & 24 patients \\
\hline 8. & $\begin{array}{l}\text { The Effect of Religious Relaxation } \\
\text { Therapy on Improving Sleep Quality of } \\
\text { Patients Chronic Kidney Failure: A Pilot } \\
\text { Study in Surabaya }\end{array}$ & Purwanti et al. (2020) & $\begin{array}{l}\text { Bangladesh Journal of } \\
\text { Medical Science (Q3) }\end{array}$ & $\begin{array}{l}\text { Quasi-experiment } \\
\text { dengan pendekatan } \\
\text { pretest-posttest } \\
\text { with control group } \\
\text { design }\end{array}$ & RSI Surabaya & 60 patients \\
\hline 9. & $\begin{array}{l}\text { Terapi Islamic Self-Healing terhadap Life } \\
\text { quality pada Klien Gagal Ginjal Kronis } \\
\text { dengan Terapi Hemodialisa }\end{array}$ & Cita et al. (2016) & $\begin{array}{l}\text { Indonesian Journal of } \\
\text { Nursing Practices (S3) }\end{array}$ & Kualitatif & Daerah Yogyakarta & 5 patients \\
\hline
\end{tabular}

find out the contents of each article. Explanation with the PRISMA diagram as follows (Figure 1):

\section{Results}

The entire literature obtained in this study has similarities in the research sample of patients undergoing hemodialysis. The difference in research articles/journals lies in the design, location, and number of research samples (Table 1).

\section{Spiritual treatment shape}

Spiritual treatment with interventions in the form of breathing relaxation exercises Shukr (thankful) and many times of remembrance has been proven to reduce the level of depression and improve the meaning of life of patients who are undergoing hemodialysis [17]. Breathing Shukr (thankful) is done by advising the patient to breathe in a deep breath while giving thanks for all the blessings gained during life. When relaxing deep breaths, there will be a process in which oxygen flows in blood vessels and body tissues so that the body becomes relaxed. Meanwhile, repeatedly saying the dhikr phrases such as Astaghfirullaha'adzim, Subhanallah, and Alhamdulillah that focus on asking for forgiveness from God will make a person feel stronger in dealing with problems and by surrendering to God will produce hope and positive thinking in individuals.

\section{Fulfillment of sleep needs}

CRF patients who are undergoing hemodialysis generally have problems in the functional aspects of the body. One of them is the physical aspect. Participants claimed that they experienced decreased activity due to physical fatigue, decreased body function due to weak muscles and bones, and discomfort due to symptoms such as nausea and pain. The disruption of sleep activity can be nightmares, waking up at night, and waking up until the morning. As a result, disruption of sleep activity will have an impact on low quality sleep [18]. Bad habits or rituals before going to sleep are also one of the causes of a decreased sleep quality of an individual [19].

Using indicators such as expressing gratitude to God by saying Alhamdulillah and expressing surrender to Allah can bring one's feelings closer to Allah SWT, resulting in a calm mind and the effects of relaxation. The final result is the creation of a good quality of sleep so that the impact will lead to a good life quality [20].

Religious relaxation, which includes preparation for sleep, performing relaxation techniques, and saying prayers, can create a calm mind and comfort that helps trigger drowsiness. The individual can start sleeping early and feel comfortable when waking up in the morning [19]. The creation of good sleep quality will have an impact on improving life quality. 


\section{Coping stimulation}

Besides experiencing disturbances in the physical aspect, CRF patients undergoing hemodialysis have problems in psychological aspects. Maladaptive coping mechanisms arise in themselves, such as feeling sadness, anxiety, and emotional instability. Participants also expressed feelings of uselessness and decreased self-esteem because they felt that they were unable to do activities like people in general [18]

Spiritual therapy has the goal to increase the strength of individuals by applying positive thinking, guiding individuals in solving problems, and encouraging individuals to learn to forgive, which of course is implemented by using a spiritual approach [21].

Participants with CRF disease undergoing hemodialysis also revealed that they experienced disruption in relationships and social interactions. Participants confessed that they felt ashamed to interact with others because of the problem of bad breath experienced and felt left out by family members [18]. An adaptive coping will be formed in the individual so that the life quality will improve [22].

\section{Quality of life improvement}

One of the factors that can affect the life quality of individuals is the support or support from the social environment. Caring behavior referred to is merely interacting and therapeutic communication continuously in the sense that the nurse is only physically present or has been presented holistically both physically, mentally, emotionally, and spiritually [23].

Nurse caring behavior can be applied in the form of attendance such as communicating with sensitivity and empathy, listening to complaints, and understanding the needs that are very necessary for patients related to their condition. Spiritual needs are usually more pronounced when individuals experience emotional stress pressure due to chronic illness. It is intended that by recognizing the spiritual needs of patients and responding correctly to those needs, we would be able to strengthen adaptive coping and improve patients' spirituality, resulting in the creation of well-being for all. Religiosity and spiritual coping with spiritual coping HRQOL for hemodialysis patients [24].

In line with that research, there is a significant relationship between a person's spirituality and the life quality of patients who undergoing hemodialysis [25]. If the needs of spirituality are not fulfilled, the impact will also affect the patient's life quality. Islamic self-healing therapy has been shown to effectively improve the life quality of patients undergoing hemodialysis, as evidenced by an increase in life quality values before and after therapy implementation. In addition, the participants feel changes after the intervention, such as the physical aspects of the participants feel a lighter body, decreased blood pressure, increased appetite, feel excited in the activity, and sleep becomes easier and more restful [18]. Psychologically, individuals reported feeling secure, relaxed, and unconcerned. Participants said that they were able to be more patient with their anger, that they were able to accept the conditions they encountered by surrendering to God's provisions, and that their spirituality and believe in God increased. In terms of social contacts and environment, the participants felt as though they had dared to leave the house to just meet and converse with neighbors.

\section{Discussion}

Spiritual caring can be done by teaching breathing relaxation accompanied by gratitude and remembrance

Spiritual caring is the behavior of nurses in giving attention to their patients through a spiritual approach by teaching breathing relaxation as the fastest and easiest way to overcome anxiety. The way to do this is to take a deep breath, then exhale slowly through your mouth like you're about to blow up a balloon. Spiritual caring can also be done by teaching patients to be grateful, as well as dhikr. Gratitude is a picture of pleasure and shows it on the surface, there are many ways of expressing gratitude in Islam, such as praying, dhikr, and always thinking positively to Allah SWT, while dhikr is a way to get closer to Allah SWT, with dhikr someone will be good and happy.

Spiritual therapy is able to overcome the problem of decreasing sleep quality in CKD patients

Sleep quality is a measure of the ease with which a person can initiate sleep and maintain sleep, including how to prepare for sleep, sleep depth, ability to stay asleep, ease of falling asleep without assistance. Spiritual therapy by teaching the patient to get closer to the creator and submission to the creator makes the patient more accepting of his situation, thus making the patient more comfortable and calmer, thus having an impact on improving the patient's sleep quality.

Spiritual caring has been able to stimulate the coping of CKD patients into adaptive coping

Coping is a method used by individuals in solving problems, adjusting to change and responding to threatening situations, adaptive coping is a coping mechanism that supports the integrase function of growth, learning and achieving goals. Sincere attention from a nurse by instilling deep spiritual values fosters the patient's enthusiasm to immediately accept his situation and try to obtain his health status through a good program, and divert his discomfort with positive things such as getting closer to God, and improve his relationship with God

Caring behavior of nurses can affect the quality of life of CKD patients 
Quality of life is an individual's perception of his position in life, in the context of the culture, value system in which they are located and their relationship to life goals, expectations, standards, and other related matters. Quality of life as the level of individual life satisfaction in the areas of physical, psychological, social, activity, material, and needs. Quality of life is directly affected by positive parenting experiences, negative parenting experiences, and chronic stress. Caring for nurses is a positive parenting experience and social resource that has a direct impact on quality of life. Other factors that affect the quality of life include self-awareness, adaptation, feeling the suffering of others, feelings of love and affection, being optimistic, developing an attitude of empathy.

\section{Conclusion}

Spiritual caring can be done by teaching breathing relaxation accompanied by gratitude and remembrance. Spiritual therapy can overcome the problem of decreasing sleep quality in CKD patients. Spiritual caring has been able to stimulate the coping of CKD patients into adaptive coping. The caring behavior of nurses can affect the quality of life of CKD patients.

\section{References}

1. WHO. Palliative Care, WHO News-Room. Geneva: WHO; 2020.

2. Health Ministry of Indonesia. Health Profile. Jakarta: Health Ministry of Indonesia; 2019.

3. Combs SA, Davison SN. Palliative and end-of-life care issues in chronic kidney disease. Curr Opin Support Palliat Care. 2015;9(1):14-9. https://doi.org/10.1097/ SPC. 0000000000000110 PMid:25581447

4. Joshi U, Subedi R, Poudel P, Ghimire PR, Panta S, Sigdel MR. Assessment of quality of life in patients undergoing hemodialysis using WHOQOL-BREF questionnaire: A multicenter study. Int J Nephrol Renovasc Dis. 2017;10:195-203. https://doi. org/10.2147/IJNRD.S136522

\section{PMid:28790861}

5. Gambaran Kualitas Hidup Pasien Gagal Ginjal Kronis Yang Menjalani Terapi Hemodialisa-Suwanti-Jurnal Keperawatan Jiwa(JKJ)-Persatuan Perawat Nasional Indonesia; 2019.

6. Nugroho P. Apakah hemodialisis tiga kali seminggu lebih baik? J Penyakit Dalam Indones. 2017;4(3):103. https://doi. org/10.7454/jpdi.v4i3.142

7. Gambaran Tingkat Depresi Pasien Gagal Ginjal Kronik Yang Menjalani Hemodialisis-Wakhid-Jurnal Keperawatan Jiwa(JKJ)Persatuan Perawat Nasional Indonesia; 2019.

8. Nurses as Palliative Care Givers for the Cancer PatientsLiterature Review-Theseus; 2020.

9. Kebutuhan Spiritual pada Pasien Kanker-Nuraeni-Jurnal Keperawatan Padjadjaran; 2015.
10. Mashitah MW. Quran recitation therapy reduces the depression levels of hemodialysis patients. Int J Res Med Sci. 2020;8(6):2222-7.

11. Durmuş M, Ekinci M. The effect of spiritual care on anxiety and depression level in patients receiving hemodialysis treatment: A randomized controlled trial. J Relig Health. 2021;60(4):1-15. https://doi.org/10.1007/s10943-021-01386-4 PMid:34387797

12. Muzaenah T. An overview of the spiritual perception of chronic kidney failure patients undergoing hemodialysis. J Keperawatan Kesehatan. 2020;11(2):23-32.

13. Armiyati $Y$, Wuryanto $E$, Sukraeny $N$. Management of psychosociospiritual problems of chronic kidney disease (CKD) patients with hemodialysis in Semarang City. Rakernas Aipkema. 2016;1(1):399-407.

14. Fradelos EC, Alikari V, Tsaras K, Papathanasiou IV, Tzavella F, Papagiannis $\mathrm{D}$, et al. The effect of spirituality in quality of life of hemodialysis patients. J Relig Health. 2021;60(1):1-12. https:// doi.org/10.1007/s10943-020-01153-x

PMid:33411225

15. Fradelos EC, Tzavella F, Koukia E, Papathanasiou IV, Alikari V, Stathoulis J, et al. Integrating chronic kidney disease patient's spirituality in their care: Health benefits and research perspectives. Mater Sociomed. 201527(5):354-8. https://doi. org/10.5455/msm.2015.27.354-358

PMid:26622206

16. Ismail $\mathrm{S}$, Hatthakit $\mathrm{U}, \mathrm{Chinawong} \mathrm{T}$. Caring science within islamic contexts: A literature review. Nurse Med J Nurs. 2015;5(1):34. https://doi.org/10.14710/nmjn.v5i1.10189

17. Meningkatkan Ketenangan Hati Pasien CKD (Chronic Kidney Disease) yaNg Menjalani Terapi Hemodialisa dengan Spiritual Hypnotherapy; 2019

18. Terapi Islamic Self Healing Terhadap Quality of life pada Klien Gagal Ginjal Kronis Dengan Terapi Hemodialisa, Cita, IJNP (Indonesian Journal of Nursing Practices); 2016.

19. Purwanti R, Yusuf A, Endang $H$, Qomariah SN, Bakar A The effect of religious relaxation therapy on improving sleep quality of patients chronic kidney failure: A pilot study in surabaya. Bangladesh J Med Sci. 2020;19(1):48-52. https://doi. org/10.3329/bjms.v19i1.43872

20. Hasina SN, Sukartini T, Setiyowati E. Setiyowati E. Effect of sleep hygiene and deep breathing exercise with spiritual care on sleep quality and quality of life of hemodialysis patient in ahmad yani islamic hospital surabaya. J Ners Kebidanan Indones. 2019;6(2):56. https://doi.org/10.21927/ jnki.2018.6(2).56-67

21. Parise M, Gatti F, lafrate R. Religiosity, marital quality and couple generativity in italian couples belonging to a catholic spiritual association: A quali-quantitative study. J Relig Health. 2017;56(5):1856-69. https://doi.org/10.1007/ s10943-016-0346-0

22. Mazandarani HK, Asadzandi M, Saffari M, Khaghanizadeh M The effect of spiritual care based on sound heart model on quality of life in hemodialysis patients. J Psychiat Behav Health For. 2018;1(1):1006.

23. Fadilah $\mathrm{N}$, Wijayanti $\mathrm{D}$, Tumini $\mathrm{T}$. Improving the quality of life of hemodialysis patients in terms of the caring behavior of nurses in RSUD Dr. Soetomo surabaya. J Kesehat Manarang. 2017;2(1):26. https://doi.org/10.33490/jkm.v2i1.10

24. Cruz JP, Colet PC, Alquwez N, Inocian EP, Al-Otaibi RS, Islam SM. Influence of religiosity and spiritual coping on health-related quality of life in Saudi haemodialysis patients. Hemodial Int. 2017;21(1):125-32. https://doi.org/10.1111/hdi.12441 PMid:27329681

25. Hubungan Antara Kesejahteraan Spiritual Dengan Kualitas Hidup Pada Pasien Gagal Ginjal Kronis; 2021. 